\title{
RANCANG BANGUN SISTEM INFORMASI AKREDITASI SEKOLAH
}

\section{(Design and Development of School Accreditation Information System)}

\author{
Ni Made Puspitayanti, Ida Bagus Ketut Widiartha*, Sri Endang Anjarwani \\ Program Studi Teknik Informatika, Fakultas Teknik, Universitas Mataram \\ JI. Majapahit 62, Mataram, Lombok NTB, INDONESIA \\ Email: dekphita@gmail.com, widi@unram.ac.id, endang@unram.ac.id
}

\begin{abstract}
School accreditation is public accountability carried out objectively, fairly, transparently and comprehensively. The instruments used in the school accreditation assessment process refer to the National Education Standards which have eight Standard Points. Since, there are many standards and criteria that must be met, the school will difficult to fulfill and measure its performance. This study aims to assist schools in carrying out the performance evaluation process, to meet the standards and criteria that refer to the National Education Standards. In this study a system was developed that can help prepare school accreditation, by providing forms that must be filled in by the school and the system will automatically measure school performance, so that the school can find out its weaknesses to be improved immediately. In its development the laravel framework was used with PHP, HTML and JavaScript as a programming language. The development method used was the waterfall method. System testing in this study uses three testing methods, namely unit testing, black box and MOS (Mean Opinion Score).
\end{abstract}

Keywords: School accreditation, laravel framework, waterfall, black box, unit testing, MOS

*Penulis korespondensi

\section{Pendahuluan}

Akreditasi merupakan akuntabilitas publik yang dilakukan dengan objektif, adil, transparan dan komprehensif dengan menggunakan instrumen dan kriteria yang mengacu pada Standar Nasional Pendidikan[1][2]. Terdapat delapan Standar Nasional Pendidikan yang dijadikan penilaian akreditasi yaitu: standar isi, standar proses, standar kompetensi lulusan, standar pendidik dan tenaga kependidikan, standar sarana dan prasarana, standar pengelolaan, standar pembiayaan, dan standar penilaian [3]. Banyaknya aspek penilaian instrumen akreditasi, sekolah tidak dapat mengantisipasi jatuhnya beberapa point akreditasi pada instrumen tersebut. Oleh karena itu diperlukan sebuah sistem yang dapat membantu sekolah dalam mempersiapkan akreditasi sekolah untuk mengantisipasi kemungkinan point akreditasi yang jatuh.

Berdasarkan pada data BAP S/M (Badan Akreditasi Provinsi Sekolah/Madrasah) terdapat 13 Sekolah Menengah Pertama (SMP) dan Madrasah Tsanawiyah (MTs) di Kota Mataram yang melakukan akreditasi pada tahun 2017. Pada saat ini penilaian akreditasi masih menggunakan excel sehingga nilai akreditasi sekolah tidak dapat selalu di-update. Pengumpulan data pendukung akreditasi sekolah juga masih dalam bentuk word serta dalam pengisian instrumen akreditasi, sekolah harus mengecek form pengumpulan data pendukung akreditasi untuk mengetahui berapa nilai isian akreditasi yang di dapatkan sekolah. Sekolah juga tidak dapat mengetahui bagaimana perkembangan nilai evaluasi diri sekolah. Nilai evaluasi diri sekolah diperoleh berdasarkan nilai akreditasi sekolah yang didapat setelah mengisi instrumen pengumpulan data dan informasi sekolah. Penilaian akreditasi sekolah saat ini hanya dapat dilakukan ketika sekolah akan melakukan akreditasi ulang atau akreditasi sekolah telah kedaluwarsa. Oleh karena itu diperlukan sebuah tools yang dapat menangani masalah tersebut.

Berdasarkan pada latar belakang di atas maka pada penelitian ini dibangun adalah sistem informasi akreditasi sekolah, yang diharapkan dapat membantu sekolah dalam pengisian borang atau data isian akreditasi serta dapat melakukan pengecekan data pada instrumen pengumpulan data dan informasi pendukung akreditasi sekolah agar sekolah dapat langsung mengetahui nilai borang yang didapatkan pada tiap butir borang yang ada. Sekolah juga dapat melakukan update nilai akreditasi setiap ada perubahan data sekolah pendukung akreditasi dan mengetahui perkembangan nilai evaluasi diri sekolah berdasarkan nilai yang didapatkan sekolah setelah 
mengisi instrumen pengumpulan data dan informasi sekolah. Sistem juga mampu merangking peringkat sekolah berdasarkan nilai akhir akreditasi yang didapatkan sekolah, sehingga diharapkan dapat memicu sekolah untuk meningkatkan akreditasinya

\section{TINJAUAN PUSTAKA}

Penelitian terkait dengan upaya membantu akreditasi sudah cukup banyak dilakukan, ada yang dibangun berbasis web[4][5] dan ada juga dibangun berbasis desktop[6]. Dalam upaya tersebut ada yang membangun sistem untuk dapat melakukan simulasi penilaian akreditasi untuk tingkat SMA/MA/SMK[5] ada juga yang membangun untuk tingkat program studi pada suatu perguruan tinggi, yang menghasilkan buku borang 3A[4]. Pada penelitian ini lebih ditekankan pada pemenuhan data pendukung seperti informasi dosen, pegawai, dan arsip kegiatan yang telah dilakukan.

Metode pengembangan yang digunakan sebagian besar menggunakan metode pengembangan waterfall karena walaupun metode ini merupakan metode klasik namun tahapan pengembangan sangat jelas dan sangat terstruktur.

Terkait dengan tinjauan pustaka tersebut pada penelitian ini dilakukan penelitian terhadap permasalahan yang hampir sama yaitu terkait dengan akreditasi sekolah yang dalam hal ini mengambil data dari Dinas Pendidikan dan Kebudayaan Kota Mataram dengan judul penelitian Rancang Bangun Sistem Informasi Sekolah. Dalam penelitian disamping menyediakan form isian seperti pada penelitian sebelumnya juga diberikan fasilitas pemeringkatan sekolah berdasarkan score yang didapat dari isian form tersebut. Pengembangan sistem digunakan framework Laravel, yang menggunakan konsep MVC (Model, View, Controller) yang memudahkan programmer dalam memperluas chasing, session, database dan fungsi otentifikasi[7].

\section{Metode Peneltian}

Pengembangan sistem yang digunakan pada penelitian ini yaitu waterfall seperti ditunjukkan pada Gambar 1. Model waterfall digunakan dalam pengembangan sistem ini karena prosesnya mengalir secara sistematis dari satu tahap ke tahap yang lain sehingga mudah untuk digunakan dalam pengembangan suatu sistem[1]. Adapun perancangan sistem yang dilakukan adalah sebagai berikut:

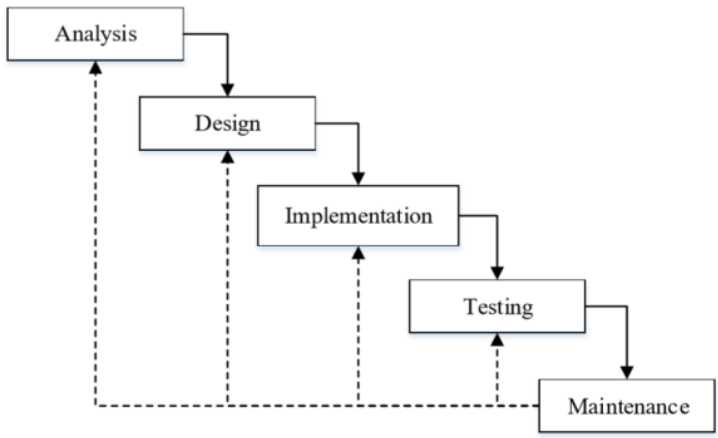

Gambar 1. Model pengembangan sistem waterfall

Model waterfall digunakan dalam pengembangan sistem ini karena prosesnya mengalir secara sistematis dari satu tahap ke tahap yang lain sehingga mudah untuk digunakan dalam pengembangan suatu sistem[8]. Adapun perancangan sistem yang dilakukan adalah sebagai berikut:

\subsection{Analisis}

Analisis yang dilakukan berupa analisis sistem yang sedang berjalan, analisis sistem yang akan dibangun dan analisis kebutuhan dalam membangun sistem.

\subsubsection{Analisis sistem yang sedang berjalan}

Pada saat ini penilaian akreditasi masih menggunakan excel dan pengumpulan data pendukung akreditasi masih dalam bentuk word serta dalam pengisian instrumen akreditasi atau data isian akreditasi, sekolah harus mengecek form pengumpulan data pendukung akreditasi untuk mengetahui berapa nilai isian akreditasi yang di dapatkan sekolah

\subsubsection{Analisis sistem yang akan dibangun}

Sistem yang akan dibangun adalah sistem akreditasi sekolah untuk membantu sekolah dalam melakukan pengisian instrumen akreditasi atau data isian akreditasi. Pada sistem yang dibangun ini sekolah dapat mengetahui nilai tiap butir borang atau isian akreditasi sekolah berdasarkan instrumen pengumpulan data dan informasi akreditasi yang telah diinputkan. Sekolah juga dapat mengetahui perkembangan nilai evaluasi diri sekolah setiap tahun setelah mengisi instrumen pengumpulan data pendukung sekolah

\subsubsection{Analisis Kebutuhan}

Analisis kebutuhan dilakukan untuk mendapatkan informasi dan data yang diperlukan dalam membangun sistem dengan melakukan observasi, wawancara dan studi literatur. Observasi dilakukan dengan datang ke 
BAP S/M untuk mendapatkan data yang diperlukan dalam pembuatan sistem yang akan dibangun. Wawancara dilakukan kepada pegawai BAP S/M dengan mengajukan beberapa pertanyaan kepada narasumber untuk mendapatkan informasi mengenai sistem yang sedang berjalan. Studi literatur dilakukan untuk mendapatkan informasi mengenai bagaimana

proses akreditasi sekolah dan data apa saja yang diperlukan. Data yang diperlukan dalam pembuatan sistem akreditasi sekolah adalah instrumen akreditasi atau data isian akreditasi, instrumen pengumpulan data dan informasi pendukung akreditasi, petunjuk teknis pengisian instrumen akreditasi dan teknik penskoran dan pemeringkatan hasil akreditasi. Adapun flowchart yang digunakan dalam melakukan penilaian akreditasi dapat dilihat pada Gambar 2 .

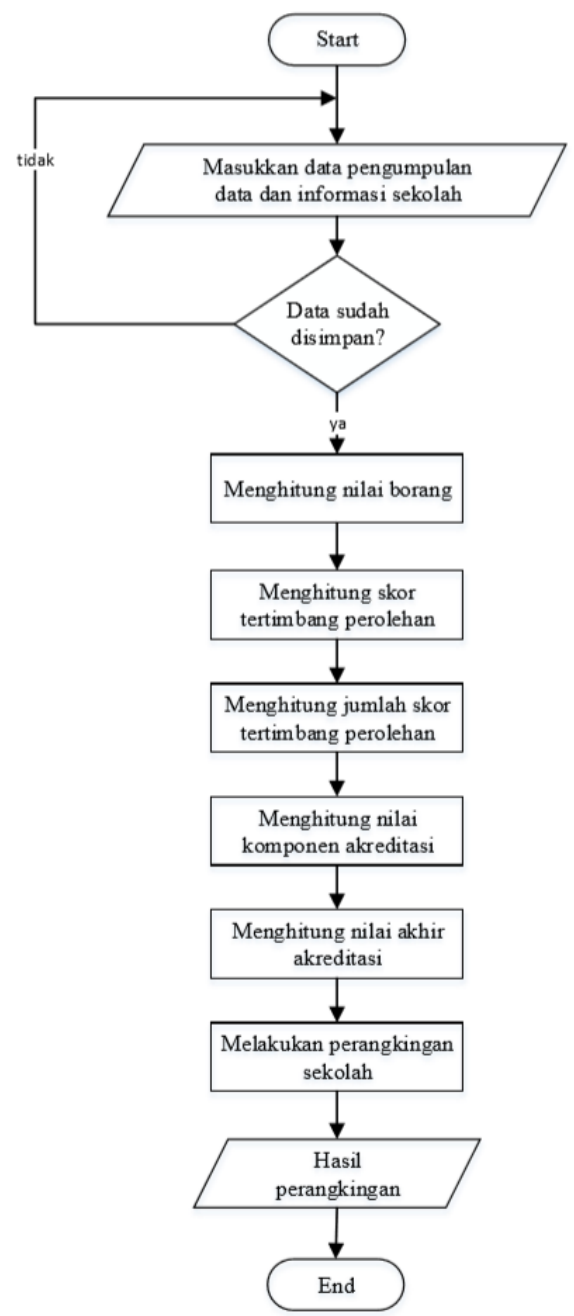

Gambar 2. Flowchart sistem akreditasi sekolah

\subsection{Perancangan}

\subsubsection{Perancangan interaksi user dengan sistem}

Tahap ini merupakan perancangan interaksi user dengan sistem menggunakan use case diagram[9].
Perancangan ini dilakukan agar para pengguna mengetahui proses apa saja yang dapat dilakukan di dalam sistem. Perancangan interaksi user dengan sistem dapat dilihat pada Gambar 3.

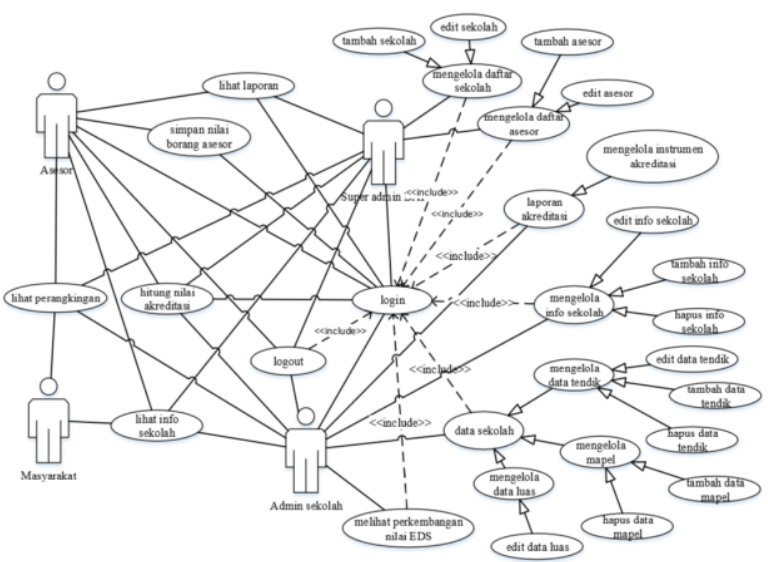

Gambar 3. Perancangan interaksi user dengan sistem

\subsubsection{Perancangan Database}

Tahap ini merupakan tahap perancangan database dimana data-data yang ada pada sistem ini seluruhnya akan disimpan dalam satu database[10], sehingga data menjadi terintegrasi. Perancangan database sistem dapat dilihat pada Gambar 4

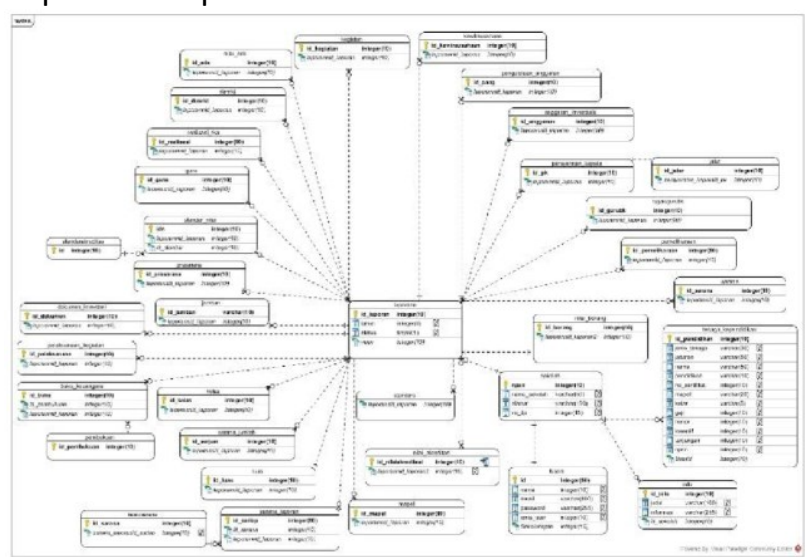

Gambar 4. Perancangan database

\section{Hasil dan PEMBahasan}

\subsection{Implementasi}

Pada implementasi sistem terdapat beberapa tampilan interface sistem berdasarkan pengguna sistem ini yang terdiri dari, admin Badan Akreditasi Provinsi Sekolah/Madrasah, admin sekolah, assessor sekolah dan masyarakat. Berikut hasil dari implementasi interface dapat dilihat pada Gambar 5 sampai Gambar 10. 


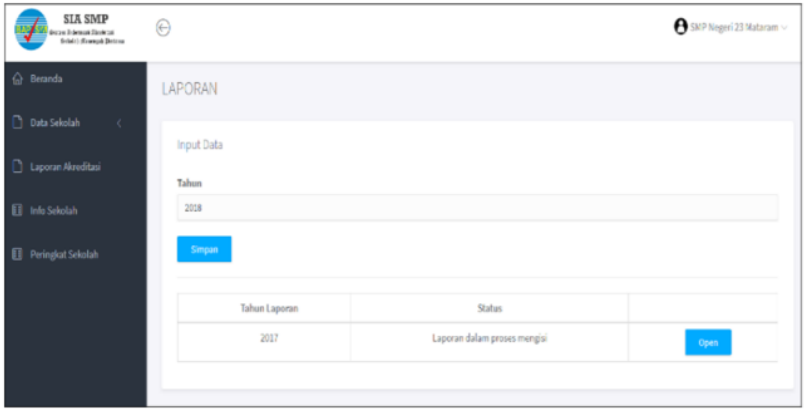

Gambar 5. Tampilan laporan akreditasi

Gambar 5 merupakan tampilan laporan akreditasi sekolah, dimana pada tampilan ini sekolah dapat membuat laporan akreditasi setiap tahun. Isi dari masing-masing laporan dapat dilihat dengan menekan tombol open pada laporan seperti pada Gambar 6.

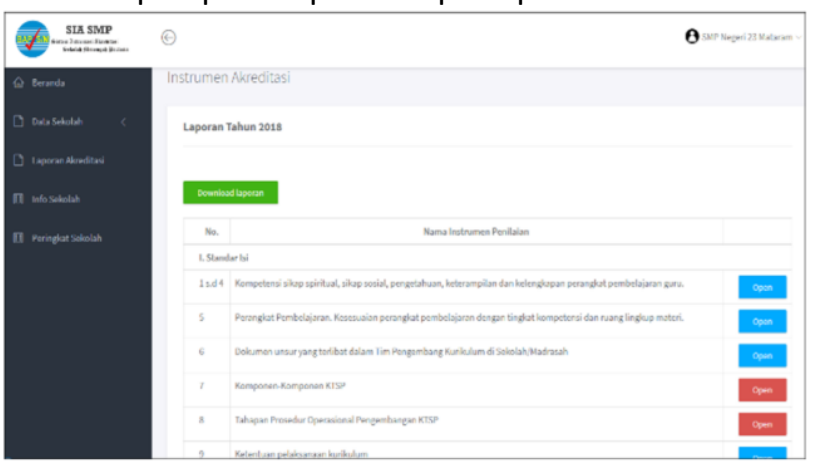

Gambar 6. Laporan instrument akreditasi sekolah

Gambar 6 merupakan tampilan dari isi laporan instrumen akreditasi, dimana pada tampilan ini terdapat 124 poin data instrumen akreditasi, dimana masing-masing poin harus diisi oleh sekolah untuk dapat mengetahui berapa nilai yang didapatkan pada poin tersebut. Setelah masing-masing poin diisi maka dapat dilihat hasil dari setiap borang atau data isian akreditasi seperti pada Gambar 7.

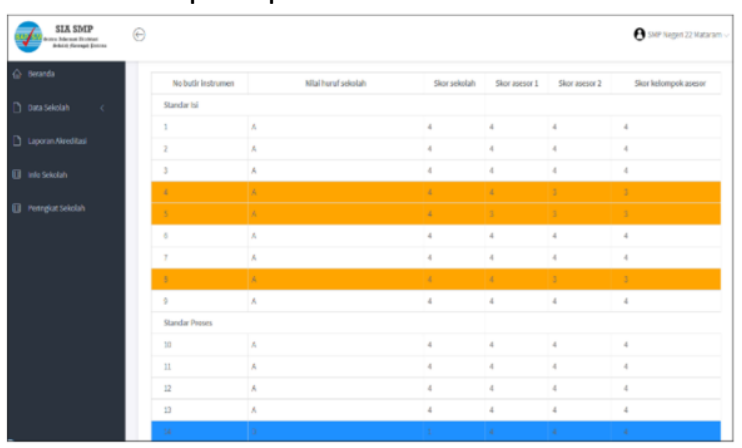

Gambar 7. Tampilan nilai isian akreditasi atau borang

Gambar 7 merupakan tampilan dari nilai data isian akreditasi sekolah yang didapatkan sekolah berdasarkan data instrumen yang telah diisi dan nilai yang diperoleh berdasarkan penilaian assessor. Setelah nilai borang atau data isian akreditasi didapat maka dapat dilihat pula nilai akreditasi yang didapatkan sekolah seperti pada Gambar 8.

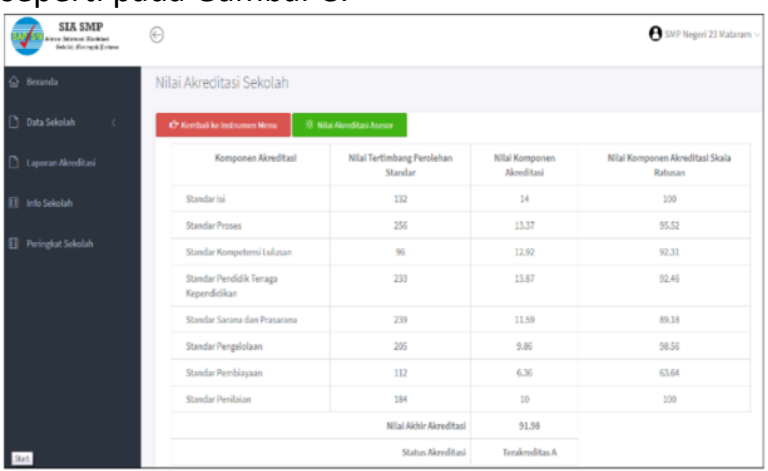

Gambar 8. Tampilan nilai akreditasi sekolah

Gambar 8 merupakan tampilan nilai akreditasi yang didapatkan oleh sekolah setelah semua data instrumen akreditasi diisi. Sekolah juga dapat melihat peringkat sekolah dan perkembangan nilai akreditasi sekolah pada Gambar 9 dan Gambar 10.

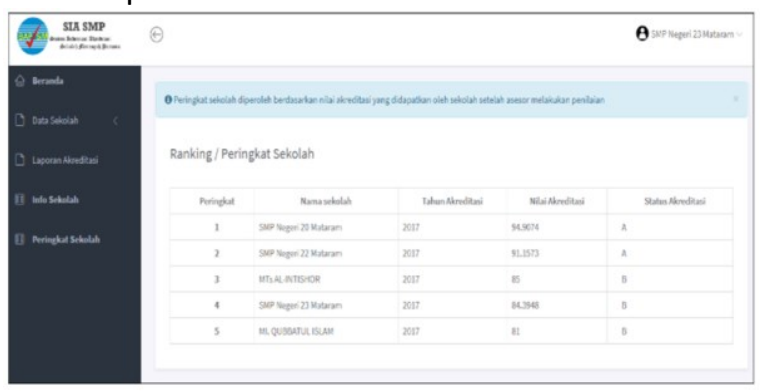

Gambar 9. Tampilan peringkat sekolah

Gambar 9 merupakan tampilan peringkat sekolah, dimana peringkat sekolah ini didapatkan berdasarkan nilai akhir akreditasi yang diurutkan dari nilai terbesar ke nilai terkecil.

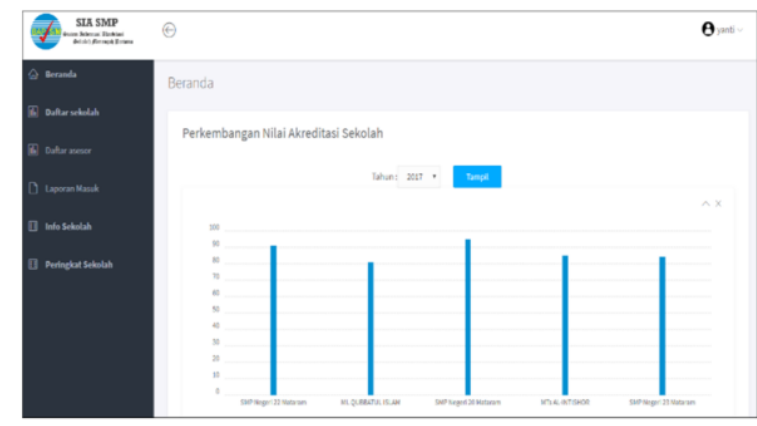

Gambar 10. Tampilan grafik perkembangan nilai akreditasi sekolah

Gambar 10 merupakan tampilan grafik perkembangan nilai akreditasi sekolah. Dengan adanya 
grafik ini maka dapat dilihat bagaimana perkembangan nilai akreditasi sekolah.

\subsection{Pengujian Sistem B.1.}

\subsubsection{Pengujian Black Box}

Metode pengujian black box merupakan metode pengujian yang menguji fungsi-fungsi di dalam sistem untuk mengetahui apakah fungsi-fungsi yang ada sesuai harapan atau tidak. Hasil pengujian black box menunjukkan semua fungsi yang ada dalam sistem ini telah berjalan dengan baik.

\subsubsection{Pengujian Unit Testing}

Pengujian unit testing digunakan untuk menguji rumus penilaian akreditasi yang ada dengan fungsi program yang telah dibuat, apakah sesuai atau tidak. Berdasarkan pada pengujian yang telah dilakukan dapat disimpulkan bahwa hasil perhitungan nilai akreditasi menggunakan program dengan perhitungan manual mendapatkan hasil yang sama.

\subsubsection{Pengujian MOS (Mean Opinion Score)}

Pengujian menggunakan kuesioner dilakukan oleh 30 responden yang menjadi pengguna sistem yang terdiri dari 18 orang dari masyarakat, 5 orang BAP S/M, 2 orang assessor akreditasi sekolah dan 5 orang dari sekolah. Pengujian sistem dilakukan secara server side, dengan cara menjalankan program pada server localhost secara stand alone. Adapun pertanyaan yang terdapat pada kuesioner adalah sebagai berikut:

1. Kuesioner pengujian untuk BAP S/M terdiri dari 10 pertanyaan, yaitu:

- Komposisi warna website sudah sesuai?

- Desain tampilan website mudah dipahami? ? Navigasi yang disajikan mudah ditelusuri?

- Sistem ini mampu menampilkan grafik perkembangan nilai akreditasi sekolah?

- Sistem ini dapat menginputkan, mengubah dan menyimpan data sekolah?

- Sistem ini dapat menerima laporan instrumen pengumpulan data dan informasi pendukung akreditasi sekolah yang telah terkirim?

- Sistem ini dapat memberikan informasi nilai butir akreditasi sekolah (borang)?

- Sistem ini dapat memberikan informasi nilai akreditasi sekolah?

- Sistem ini dapat memberikan informasi peringkat/ranking sekolah?
- Sistem dapat menampilkan informasi yang dibagikan sekolah?

2. Kuesioner pengujian untuk sekolah terdiri dari 10 pertanyaan, yaitu:

- Komposisi warna website sudah sesuai?

- Desain tampilan website mudah dipahami?

- Navigasi yang disajikan mudah ditelusuri?

- Sistem ini mampu menampilkan grafik perkembangan nilai akreditasi sekolah?

- Sistem ini dapat meng-input-kan, menghapus, mengubah dan menyimpan data sekolah?

- Sistem ini dapat menyimpan dan memperbaharui instrumen pengumpulan data dan informasi pendukung akreditasi sekolah?

- Sistem ini dapat memberikan informasi nilai butir instrumen akreditasi (borang)?

- Sistem ini dapat memberikan informasi nilai akreditasi sekolah?

- Sistem ini dapat memberikan informasi peringkat/ranking sekolah?

- Sistem ini dapat meng-input-kan, menghapus, mengubah dan menyimpan info sekolah?

3. Kuesioner pengujian untuk assessor terdiri dari 9 pertanyaan, yaitu:

- Komposisi warna website sudah sesuai?

- Desain tampilan website mudah dipahami?

- Navigasi yang disajikan mudah ditelusuri?

- Sistem ini mampu menampilkan grafik perkembangan nilai akreditasi sekolah?

- Sistem ini dapat menerima laporan instrumen pengumpulan data dan informasi akreditasi sekolah yang telah dikirim?

- Sistem ini dapat memberikan informasi nilai butir instrumen akreditasi (borang)?

- Sistem ini dapat memberikan informasi nilai akreditasi sekolah?

- Sistem ini dapat memberikan informasi peringkat/ranking sekolah?

- $\quad$ Sistem ini dapat menampilkan informasi yang dibagikan sekolah?

4. Kuesioner pengujian untuk masyarakat terdiri dari 5 pertanyaan, yaitu:

- Komposisi warna website sudah sesuai?

- Desain tampilan website mudah dipahami?

- Navigasi yang disajikan mudah ditelusuri? 
- Sistem ini dapat memberikan informasi peringkat/ranking sekolah?

Sistem ini dapat memberikan informasi yang dibagikan oleh masing-masing sekolah? Hasil dari jawaban kuesioner responden akan dihitung dan diambil kesimpulan sesuai dengan hasil pengujian yang dilakukan. Berdasarkan pernyataan yang ada, responden diminta untuk menjawab dengan nilai-nilai tertentu yang sudah ditentukan seperti pada Tabel I.

TABEL I. STANDAR PENILAIAN MOS NILAI MOS[11]

\begin{tabular}{|c|c|}
\hline Nilai MOS & Tingkat Kepuasan \\
\hline 5 & Sangat setuju \\
\hline 4 & Setuju \\
\hline 3 & Cukup \\
\hline 2 & Tidak setuju \\
\hline 1 & Sangat tidak setuju \\
\hline
\end{tabular}

Langkah selanjutnya yang dilakukan adalah menghitung persentase dari setiap jawaban yang diberikan oleh responden di setiap pernyataan. Rumus untuk menghitung persentase nilai adalah sebagai berikut:

$$
P_{n}=J / N * 100 \%
$$

Kemudian untuk menghitung persentase rata-rata dari setiap poin jawaban, perhitungan tersebut menggunakan rumus sebagai berikut:

$$
\text { Rerata }=\frac{\sum_{n=1}^{N} P_{n}}{N}
$$

Keterangan:

$\mathrm{P}_{\mathrm{n}} \quad$ : Persentase ke $\mathrm{n}$

J : total nilai jawaban yang diberikan responden pada setiap nomor

$\mathrm{N}$ : jumlah responden.

Rerata: Persentase rata-rata

Jadi persentase responden terhadap jawaban kuesioner yaitu sangat tidak setuju, tidak setuju, cukup, setuju, dan sangat setuju dapat dihitung secara keseluruhan dan didefinisikan sebagai nilai rata-rata. Perhitungan untuk hasil jawaban pengguna pada setiap pernyataan pada kuesioner disajikan dalam Grafik pada Gambar 11

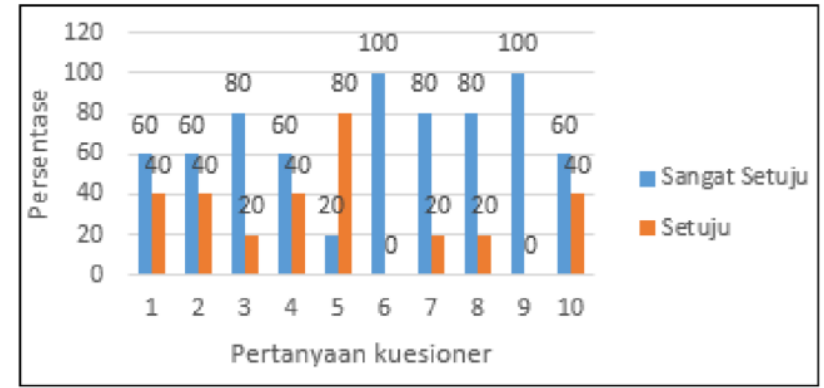

Gambar 11. Grafik persentase jawaban responden BAP S/M

Gambar 11 merupakan persentase hasil jawaban kuesioner untuk Badan Akreditasi Provinsi Sekolah/Madrasah (BAP S/M) yang melibatkan 5 orang dengan 10 pertanyaan. Persentase jawaban rataratanya dapat dilihat pada Gambar 12.

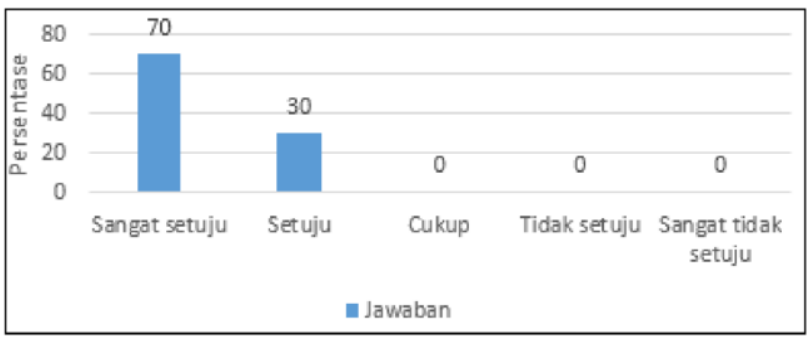

Gambar 12. Grafik persentase jawaban rata-rata responden BAP S/M

Gambar 12 merupakan grafik hasil dari perhitungan rata-rata seluruh jawaban dari pertanyaan yang ada, maka dihasilkan persentase nilai 70\% untuk jawaban sangat setuju dan $30 \%$ untuk jawaban setuju.

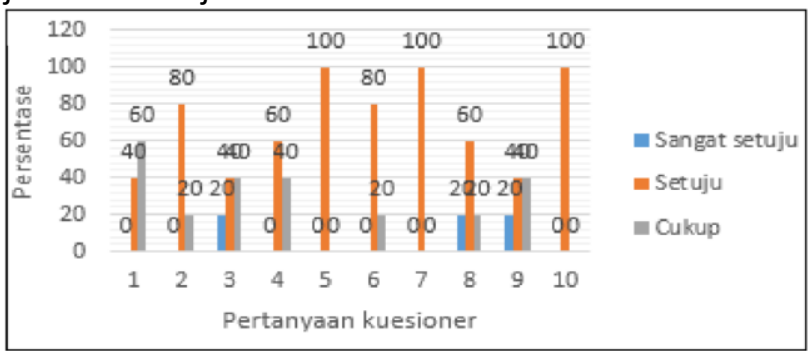

Gambar 13. Grafik persentase jawaban responden sekolah

Gambar 13 merupakan persentase hasil jawaban kuesioner untuk sekolah yang melibatkan 5 orang dengan 10 pertanyaan. Persentase jawaban rataratanya dapat dilihat pada Gambar 14. 


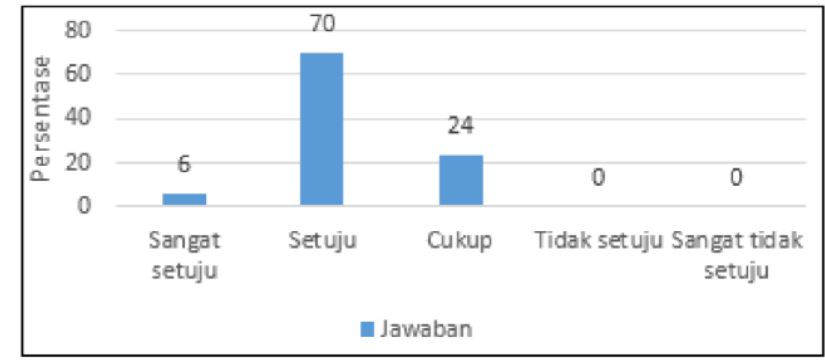

Gambar 14. Grafik persentase jawaban rata-rata responden sekolah

Gambar 14 merupakan grafik hasil dari perhitungan rata-rata seluruh jawaban dari pertanyaan yang ada, maka dihasilkan persentase nilai $6 \%$ untuk jawaban sangat setuju, $70 \%$ untuk jawaban setuju dan $24 \%$ untuk jawaban cukup.

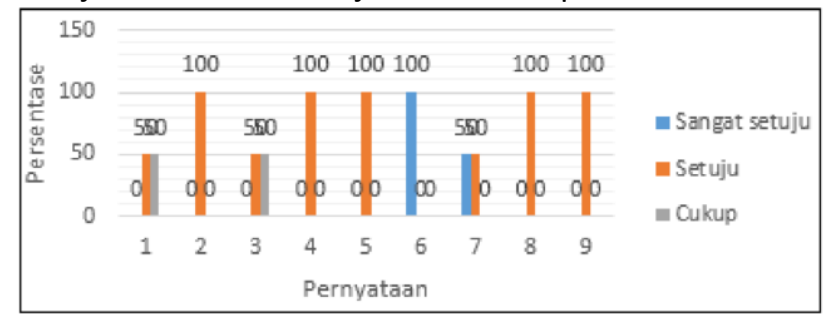

Gambar 15. Grafik persentase jawaban responden assessor

Gambar 15 merupakan persentase hasil jawaban kuesioner untuk assessor yang melibatkan 2 orang assessor

dengan 9 pertanyaan. Persentase jawaban rataratanya dapat dilihat pada Gambar 16.

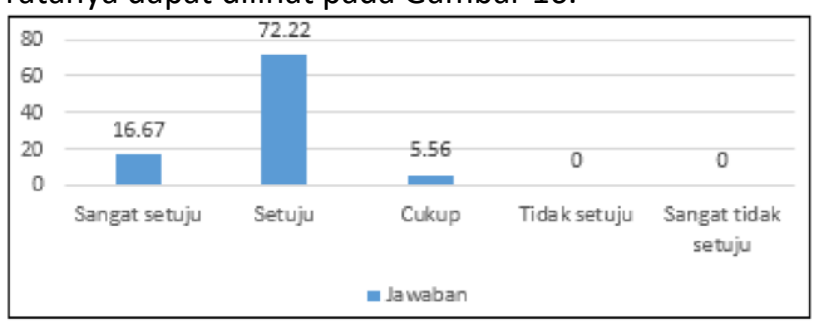

Gambar 16. Grafik persentase jawaban rata-rata responden assessor

Gambar 16 merupakan grafik hasil dari perhitungan rata-rata seluruh jawaban dari pertanyaan yang ada, maka dihasilkan persentase nilai $16.67 \%$ untuk jawaban sangat setuju, $72.2 \%$ untuk jawaban setuju dan $5.56 \%$ untuk jawaban cukup.

Gambar 17 merupakan persentase hasil jawaban kuesioner untuk masyarakat yang melibatkan 18 orang dengan 5 pertanyaan. Persentase jawaban rataratanya dapat dilihat pada Gambar 18.

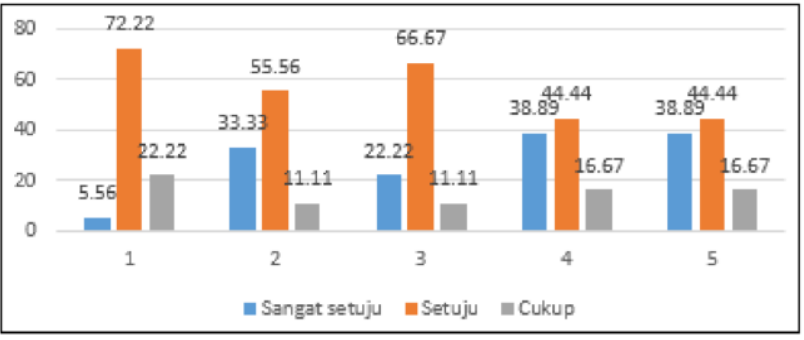

Gambar 17. Grafik persentase jawaban responden masyarakat

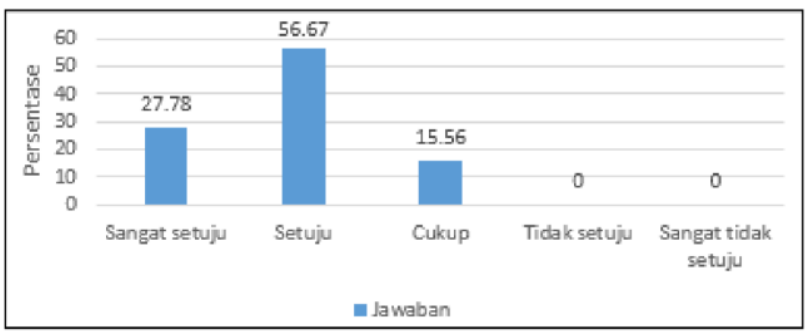

Gambar 18. Grafik persentase jawaban rata-rata responden masyarakat

Gambar 18 merupakan grafik hasil dari perhitungan rata-rata seluruh jawaban dari pertanyaan yang ada, maka dihasilkan persentase nilai 27.78 \% untuk jawaban sangat setuju, 56,67 \% untuk jawaban setuju dan $15.56 \%$ untuk jawaban cukup. Bagian ini berisi hasil dan pembahasan penelitian. Hasil penelitian disajikan bentuk tabel atau grafik yang selanjutnya diberikan deskripsi dan pembahasan atas fakta yang diperoleh dikaitkan teori pendukung penelitian dan atau dibandingkan dengan hasil penelitian yang sangat terkait lainnya.

\section{KESIMPULAN DAN SARAN}

\subsection{Kesimpulan}

Berdasarkan hasil pembahasan dan pengujian yang dilakukan maka dapat ditarik kesimpulan dalam pembangunan "Sistem Informasi Akreditasi Sekolah" sebagai berikut:

1. Sistem ini dapat digunakan untuk membantu sekolah dalam mengisi data isian akreditasi (borang).

2. Sistem ini dapat melakukan perangkingan sekolah berdasarkan nilai akreditasi.

3. Sistem ini dapat membantu sekolah dalam melakukan evaluasi diri sekolah serta melihat perkembangannya.

4. Sistem ini dapat menampilkan perkembangan nilai akreditasi sekolah. 
5. Berdasarkan hasil Pengujian menggunakan Mean Opinion Score (MOS) menunjukkan bahwa ratarata penilaian responden masyarakat terhadap sistem menyatakan sangat setuju dengan persentase $27.78 \%$ dan menyatakan setuju dengan persentase $56.67 \%$ sedangkan $15.56 \%$ menyatakan cukup. Sedangkan rata-rata penilaian responden BAP terhadap sistem menyatakan sangat setuju dengan persentase $70 \%$ dan menyatakan setuju dengan persentase $30 \%$. Sedangkan rata-rata penilaian responden sekolah terhadap sistem menyatakan sangat setuju dengan persentase $6 \%$ dan menyatakan setuju dengan persentase $70 \%$ sedangkan $24 \%$ menyatakan cukup. Serta rata-rata penilaian responden assessor terhadap sistem menyatakan sangat setuju dengan persentase $16.67 \%$ dan menyatakan setuju dengan persentase $72.2 \%$ sedangkan 5.56 \% menyatakan cukup. Sehingga dapat disimpulkan bahwa sistem ini layak digunakan untuk membantu sekolah dalam melakukan pengisian borang atau isian akreditasi dan melakukan perangkingan sekolah.

\subsection{Saran}

Adapun beberapa saran yang dapat disampaikan untuk pengembangan sistem akreditasi sekolah lebih lanjut adalah:

1. Pada penelitian selanjutnya dapat dilakukan penilaian akreditasi pada jenjang pendidikan lainnya.

2. Pada penelitian selanjutnya dapat ditambahkan fitur penyimpanan bukti-bukti yang diperlukan dalam proses penilaian akreditasi, yang dapat memudahkan sekolah ketika dilakukan visitasi.

\section{DAFTAR PUSTAKA}

[1] Presiden Republik Indonesia, Undang-Undang Republik Indonesia Nomor 20 Tahun 2003 Tentang Sistem Pendidikan Nasional. Republic Indonesia: https://kelembagaan.ristekdikti.go.id/wpcontent/uploads/2016/08/UU_no_20_th_2003.pdf, 2003.

[2] Presiden Republik Indonesia, PP 19 Tahun 2005 Tentang Standar Nasional Pendidikan. 2005.

[3] Presiden Republik Indonesia, PP 17 Tahun 2010 Tentang Pengelolaan dan Penyelenggaraan Pendidikan. Republik Indonesia, 2010.

[4] S. Nurmiati and H. Munandar, "Akreditasi Program Studi Berbasis Web Studi Kasus Program Studi Manajemen Sumberdaya Perairan -IPB," J. SISFO, vol. 5, no. 5, pp. 514-523, 2016.

[5] N. Rijati and A. Fahmi, "Perangkat Lunak Simulasi Penilaian Instrumen Akreditasi SMA/MA," in Seminar Nasional Informatika, 2010, no. 2010.

[6] A. Triwahyuni and S. Selatan, "Pengembangan Sistem Informasi Data Center Sebagai Penyedia Data Penyusun Borang," Pengemb. Sist., vol. 11, no. No 1, pp. 29-34, 2014.

[7] S. McCool, Laravel Starter. Birmingham Mumbai: Packt Publishing, 2012.

[8] A. . Rosa, Rekayasa perangkat lunak: Terstruktur dan berorientasi objek. Informatika, 2014.

[9] Haviluddin, "Memahami Penggunaan UML (Unified Modelling Language)," J. Inform. Mulawarman, vol. 6, no. 1, pp. 1-15, 2011.

[10] I. B. K. Widiartha, A. Y. Husodo, and S. E. Anjarwani, "Sistem Layanan Akademik Berbasis SMS Fakultas Teknik Universitas Mataram," Jurnal Penelitian UNRAM, vol. 18, no. 1, pp. 27-34, 2014.

[11] S. Syaifullah, I. G. P. S. Wijaya, dan A. Y. Husodo, "Sistem Informasi Kepuasan Layanan Administrasi Akademik Berbasis IPA (Importance Performance Analysis) Studi Kasus Fakultas Teknik Universitas Mataram," J. Comput. Sci. Informatics Eng., vol. 2, no. 1, 2018. 